\title{
A Study on Energy Efficient VM Allocation in Green Cloud Computing
}

\author{
Chingrace Guite $^{1^{*}}$, Kamaljeet Kaur Mangat ${ }^{2}$ \\ ${ }^{1}$ Dept. of CSE, PURCITM, Mohali, India \\ ${ }^{2}$ Dept. of CSE, PURCITM, Mohali, India \\ Corresponding Author: guitegrace.chin.gg@gmail.com, Tel.: 7085936207
}

Available online at: www.isroset.org

Accepted: 20/Aug/2018, Online: 30/Aug/ 2018

\begin{abstract}
Cloud computing plays a significant role since its evolution. With its ubiquitous nature, sharing of resources and management of services has never been convenient than ever before. Due to its ability to provide scalability and elasticity infrastructure, many organization utilizes the services, where the workload is shifted in cloud data centers. This data center consumes more power and there is the release of unwanted carbon footprint in the environment. Therefore here lies the need to improve the use of energy and at the same time minimizing power consumption. In this paper, we present a survey on VM placement and migration to achieve energy efficiency in cloud data centers.
\end{abstract}

Keywords - Power Consumption, Virtual Machine Allocation, Virtual Machine Migration, Green Computing

\section{INTRODUCTION}

Cloud computing is well known in technologies for providing service model[1]. It gives the flexibility to access resources to clients or users through means of internet. Services offer in cloud consist of Infrastructure as a Service (IaaS), Platform as a Service (PaaS), and Software as a Service (SaaS) and deployment services are public, private, hybrid and community which depicts where. Widely known companies such as IBM, Google, Amazon AWS, Dropbox provides services to users around the world.

In the cloud, data centers houses both hardware and software technology along with computing services which consume a large amount of energy violating the environment. In 2006, DataCentre knowledge explained that in USA alone datacentres consumes 70 million kilowatt-hours of electricity in 2014 and was believed to increase more than 40 billion $\mathrm{kWh}$ if not for energy efficiency measures. Moreover, the $\mathrm{CO} 2$ emission is no a secret which effects environment badly and with the improvement of energy efficiency, the survey stated that 620 billion $\mathrm{kWh}$ will be able to save between 2010 and 2020 [2]. The defining challenges as inferred in [3] gives ample explanation on how important virtualization is and the significant role and principles of cloud computing against traditional computing. Energy efficiency can be achieved with the help of virtualization which now serves as a major purpose for green cloud computing. It is still a recent exploration area under virtualization techniques and is becoming more popular than ever before. The idea is to reduce physical host in which multiple instances run along with resources on a single platform called the physical host and pave the way to revolutionized in cloud computing.

The remainder of the paper is organized as follows. A brief introduction to Virtualization is discussed in Section 2 and describes various optimization techniques to minimize the energy consumption in the cloud. In section 3 we describe related work of the previous study on VM placement and migration. Finally, Section 4 presents our conclusion.

\section{NEED OF VIRTUALIZATION}

It is not new that the cloud infrastructure itself cannot provide energy efficiency [4]. There is a tendency of more workload in cloud data centers due to immense energy consumption leading to emitting high emission of $\mathrm{CO}_{2}$ and here lies the necessity of energy efficiency. In order to analyze and predict the performance of workload, author G. Kousiouris, T. Cucinatta et al [5] focus on some parameters 
such as real-time scheduling decisions, allocation percentages, and co-placement. Virtualization techniques and tools discuss the justification for dynamic resource allocation, fault tolerance isolation and ease of management as such. Virtualization is an abstraction layer that allows multiple operating systems runs side by side with virtual machines as a single unit as depicted in fig 1 . It provides hardware independence, encapsulation, server consolidation and VM migration.

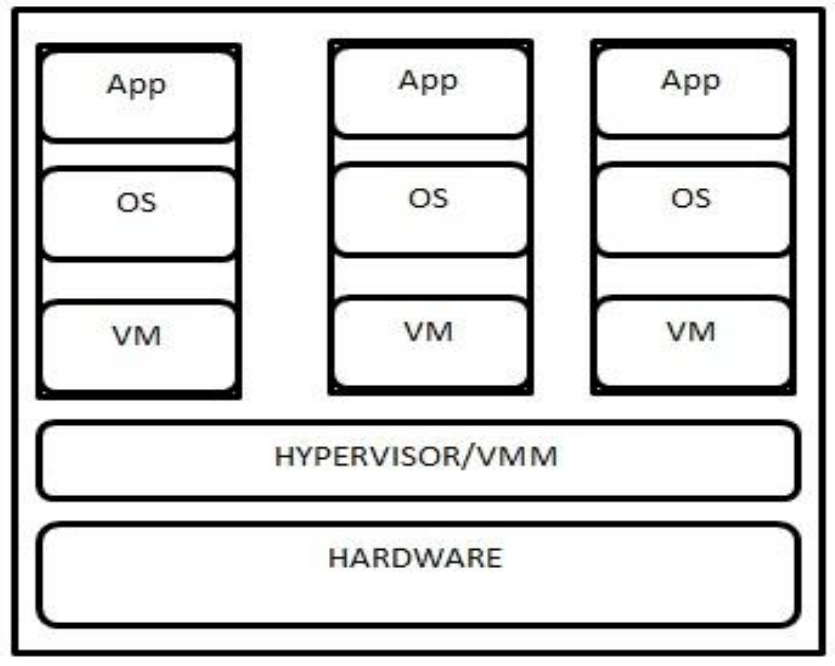

Fig:1 Virtualization[6]

The traditional workload for solution attempt to concentrate on minimizing the computing resources and increasing the number of resources to idle mode, however in [7] author briefed on GreenCloud that offers users to utilize resources on servers, switches, and link. The author of [8] presented a technique which monitors network affinity from intensive resource bottleneck among VMs (virtual machines) and migrations. The task is a dynamic adjustment in VM placement which helped to achieve minimal network contention and improve performance. Since VM selection and placement is taken into consideration it is indeed important to decide on the location of cloud infrastructure [9] and provide and meet customer requirements. In [10] the authors presented a scheduling for power-aware virtual machines placement in the cloud. In it, parameter says SLA are taken into consideration which satisfies the policy and gives less power consumption.

\section{RELATED WORK}

H.T. Vu and S. Hwang [11] put forward an algorithm with more details on energy-aware VM placement and throw some light to improve overall performance by controlling VM traffic in order to increase CPU utilization so that factor such as SLA violation and energy consumption are taken into consideration.

In [12] M. Bala and A.Green stated the importance of virtual machine migration in cloud data centers when VM face workload and focuses mainly on energy performance. Another proposed work by N.J Kansal and I. Chana on energy-aware is adapted from power aware using firefly algorithm [13] that can perform the live migration and minimizing energy consumption by selecting VM from source to destination and it tries to enhance techniques to give maximum scalability so that energy efficiency can be achieved.

Another yet discussed in [14] is explained by M. Mishra and A. Sahoo the use of vector-based technique considering different metrics and their intention to improve the existing methods are also presented with a list of properties therefore balanced servers is achieved after VM allocation. The modified algorithm of BFD (Best fit decreasing)i.e. MBFD is explained by S. Mustafa B.Nazir, A.Hayat et al [15] that which is based on the bin packing problem. In Modified BFD the Virtual machine is sorted in increasing order based on their utilization of CPU.

All Virtual machines after sorting are deployed to the host's machine based on the power or energy consumption and according to which it is then checked that how much change in power consumption of the hosts after placement of specific VM. VMs are consolidated and minimizes congestion in network hence gives better result in less cost, reduces power consumption and SLA violation.

E.P Zaw and N.L Thein [16] proposes a framework for improving further Live migration performance that reduces the number of memory pages to be transferred. The author uses Least Recent Used cache with a splay tree prediction algorithm along with working set prediction method. A comparative analysis is performed with Xen's pre-copy migration algorithm and reduces $23.67 \%$ of overall transferred while migrating.

This table describes various energy efficiency techniques, the algorithm used by the various author, and the outcomes. They have taken numerous parameters such as downtime, migration time, VM placement technique, SLA violation and power consumption. 
Table.1 : Comparison between various efficiency techniques

\begin{tabular}{|c|c|c|c|}
\hline Proposed by & $\begin{array}{c}\text { Algorithm } \\
\text { used }\end{array}$ & Description & Outcome \\
\hline $\begin{array}{l}\text { Thiago Kenji } \\
\text { et al[17] }\end{array}$ & $\begin{array}{l}\text { First fit } \\
\text { decreasing } \\
\text { (FFD), } \\
\text { GABFD and } \\
\text { PABFD }\end{array}$ & $\begin{array}{l}\text { Aims to } \\
\text { minimize } \\
\text { energy } \\
\text { consumptio } \\
\mathrm{n} \text { and also } \\
\text { the use of } \\
\text { resources is } \\
\text { optimized. }\end{array}$ & $\begin{array}{l}\text { Migration } \\
\text { time is } \\
\text { minimized } \\
\text { and hence } \\
\text { satisfies } \\
\text { Quality of } \\
\text { Service due } \\
\text { to a reduced } \\
\text { active } \\
\text { machine } \\
\text { that shifted } \\
\text { numbers of } \\
\text { workload } \\
\text { on lesser } \\
\text { machines }\end{array}$ \\
\hline $\begin{array}{l}\text { Hieu trong et } \\
\text { al[11] }\end{array}$ & $\begin{array}{l}\text { Traffic and } \\
\text { power-aware } \\
\text { Virtual } \\
\text { Machine } \\
\text { (TPVMP) }\end{array}$ & $\begin{array}{l}\text { Consolidate } \\
\text { d VM } \\
\text { utilizes } \\
\text { various } \\
\text { policies to } \\
\text { place VM }\end{array}$ & $\begin{array}{l}\text { Increase } \\
\text { overall } \\
\text { performanc } \\
\text { e and } \\
\text { minimizes } \\
\text { VM traffic } \\
\text { cost }\end{array}$ \\
\hline $\begin{array}{l}\text { Anton } \\
\text { beloglazov } \\
\text { and } \\
\text { Rajkumar } \\
\text { buyya [18] }\end{array}$ & $\begin{array}{l}\text { VM } \\
\text { placement } \\
\text { algorithm and } \\
\text { minimum } \\
\text { migration } \\
\text { (MM) policy }\end{array}$ & $\begin{array}{l}\text { VM is } \\
\text { optimized } \\
\text { continuousl } \\
\text { y and } \\
\text { follows } \\
\text { SLA } \\
\text { policies }\end{array}$ & $\begin{array}{l}\text { Consolidate } \\
\text { d VM gives } \\
\text { minimizatio } \\
\text { n of energy }\end{array}$ \\
\hline $\begin{array}{l}\text { Young } \\
\text { Choon et al } \\
{[19]}\end{array}$ & $\begin{array}{l}\text { ECTC and } \\
\text { MaxUtil } \\
\text { algorithm }\end{array}$ & $\begin{array}{l}\text { The task of } \\
\text { MaxUtil is } \\
\text { to } \\
\text { consolidate } \\
\text { VM }\end{array}$ & $\begin{array}{l}\text { Less power } \\
\text { consumptio } \\
\mathrm{n} \text { and save } \\
\text { energy. } \\
\text { Also } \\
\text { reduces the } \\
\text { carbon } \\
\text { footprint of } \\
\text { environmen } \\
\mathrm{t} \text {. }\end{array}$ \\
\hline $\begin{array}{l}\text { Nguyen } \\
\text { quang hung } \\
\text { et al[20] }\end{array}$ & $\begin{array}{l}\text { EPOBF(Energ } \\
\text { y aware and } \\
\text { performance- } \\
\text { per-watt } \\
\text { oriented Best- } \\
\text { fit ) }\end{array}$ & $\begin{array}{l}\text { Propose } \\
\text { new VM } \\
\text { allocation } \\
\text { and perform } \\
\text { comparative } \\
\text { analysis } \\
\text { with } \\
\text { PABFD }\end{array}$ & $\begin{array}{l}\text { Shows } \\
\text { significant } \\
\text { save of } \\
\text { power } \\
\text { thereby } \\
\text { reduce } \\
\text { energy } \\
\text { consumptio } \\
\text { n }\end{array}$ \\
\hline
\end{tabular}

\begin{tabular}{|c|c|c|c|}
\hline $\begin{array}{l}\text { Gregor won } \\
\text { laszewski et } \\
\text { al[21] }\end{array}$ & $\begin{array}{l}\text { Power-Aware } \\
\text { Scheduling } \\
\text { algorithm }\end{array}$ & $\begin{array}{l}\text { VM } \\
\text { dynamically } \\
\text { performed } \\
\text { in a cluster } \\
\text { in order to } \\
\text { improve } \\
\text { computing } \\
\text { performanc } \\
\text { e }\end{array}$ & $\begin{array}{l}\text { Improves } \\
\text { overall } \\
\text { execution } \\
\text { and } \\
\text { performanc } \\
\text { e hence } \\
\text { minimize } \\
\text { processor } \\
\text { power }\end{array}$ \\
\hline $\begin{array}{l}\text { A. kochut } \\
\text { and kirk } \\
\text { beaty[22] }\end{array}$ & $\begin{array}{l}\text { Presents } \\
\text { analytical } \\
\text { model VM } \\
\text { migration, the } \\
\text { time required } \\
\text { to migrate, } \\
\text { ability to } \\
\text { predict VM } \\
\text { demands and } \\
\text { due to } \\
\text { migration } \\
\text { chance } \\
\text { additional of } \\
\text { resource } \\
\text { consumption } \\
\end{array}$ & $\begin{array}{l}\text { Gives } \\
\text { apprehensiv } \\
\text { e way to the } \\
\text { dynamic } \\
\text { reallocation } \\
\text { of VM }\end{array}$ & $\begin{array}{l}\text { Migration } \\
\text { time is } \\
\text { significantly } \\
\text { minimized } \\
\text { and overall } \\
\text { improveme } \\
\text { nt due to } \\
\text { convenient } \\
\text { response } \\
\text { time during } \\
\text { VM } \\
\text { migration }\end{array}$ \\
\hline $\begin{array}{l}\text { S. S. } \\
\text { Masoumzade } \\
\mathrm{h} \text { and } \mathrm{H} . \\
\text { Hlavacs [23] }\end{array}$ & $\begin{array}{l}\text { Proposes a } \\
\text { decentralized } \\
\text { dynamic } \\
\text { consolidation } \\
\text { of VM, uses } \\
\text { three } \\
\text { approaches }\end{array}$ & $\begin{array}{l}\text { It uses live } \\
\text { migration } \\
\text { techniques } \\
\text { peerSim } \\
\text { simulation } \\
\text { tool is used } \\
\text { resulting in } \\
\text { an optimal } \\
\text { solution }\end{array}$ & $\begin{array}{l}\text { Reducing } \\
\text { energy } \\
\text { consumptio } \\
\text { n and } \\
\text { satisfies } \\
\text { QoS }\end{array}$ \\
\hline $\begin{array}{l}\text { Monil } \\
\text { al[24] }\end{array}$ & $\begin{array}{l}\text { Proposed on } \\
\text { three } \\
\text { selection } \\
\text { algorithm with } \\
\text { migration } \\
\text { control } \\
\text { strategy }\end{array}$ & $\begin{array}{l}\text { With } \\
\text { migration } \\
\text { strategy and } \\
\text { applying } \\
\text { that three } \\
\text { algorithm } \\
\text { saves } \\
\text { energy and } \\
\text { minimizes } \\
\text { the number } \\
\text { of } \\
\text { migrations }\end{array}$ & $\begin{array}{l}\text { Reduces } \\
\text { network } \\
\text { traffic and } \\
\text { improves } \\
\text { performanc } \\
\text { e than other } \\
\text { heuristics } \\
\text { approaches }\end{array}$ \\
\hline
\end{tabular}

\section{CONCLUSION}

In this paper, with the provision of a holistic view on virtualization, we reviewed and presented related to VM placement, migration and consolidation based on different techniques in order to minimize energy consumption while providing reliable quality of service. 
Some of our findings on existing work can be concluded that in the future an approach such as an Artificial neural network for selection, machine learning like Support vector machine (SVM) with genetic algorithm for optimization can be applied to improve quality of service, reduce SLA violation and attain energy efficiency.

\section{REFERENCES}

[1] T. Mundo, "Cloud Computing - Bits." .

[2] Y. Sverdlik, "Here's How Much Energy All US Data Centers Consume | Data Center Knowledge," Data Center Knowledge. 2016.

[3] Q. Zhang, L. Cheng, and R. Boutaba, "Cloud computing: State-ofthe-art and research challenges," J. Internet Serv. Appl., vol. 1, no. 1, pp. 7-18, 2010.

[4] I. Amazon Web Service, “Amazon EC2.” 2014.

[5] G. Kousiouris, T. Cucinotta, and T. Varvarigou, "The effects of scheduling, workload type and consolidation scenarios on virtual machine performance and their prediction through optimized artificial neural networks," J. Syst. Softw., vol. 84, no. 8, pp. 12701291, 2011.

[6] K. C. Gouda, A. Patro, D. Dwivedi, and N. Bhat, "Virtualization Approaches in Cloud Computing," vol. 12, no. 4, pp. 161-166, 2014.

[7] D. Kliazovich and P. Bouvry, "GreenCloud: a packet-level simulator of energy-aware cloud computing data centers," 2010.

[8] J. Sonnek, J. Greensky, R. Reutiman, and A. Chandra, "Starling: Minimizing communication overhead in virtualized computing platforms using decentralized affinity-aware migration," Proc. Int. Conf. Parallel Process., pp. 228-237, 2010.

[9] H. Qian and Q. Lv, "Proximity-aware cloud selection and virtual machine allocation in IaaS cloud platforms," Proc. - 2013 IEEE 7th Int. Symp. Serv. Syst. Eng. SOSE 2013, pp. 403-408, 2013.

[10] Í. Goiri, F. Julià, R. Nou, J. Ll Berral, J. Guitart, and J. Torres, "Energy-aware scheduling in virtualized datacenters," Proc. IEEE Int. Conf. Clust. Comput. ICCC, pp. 58-67, 2010.

[11] H. T. Vu and S. Hwang, "A Traffic and Power-aware Algorithm for Virtual Machine Placement in Cloud Data Center," 2014.

[12] M. Bala and Á. Green, "Proceedings of the International Congress on Information and Communication Technology," vol. 438, pp. 161-168, 2016.

[13] N. J. Kansal and I. Chana, "Energy-aware Virtual Machine Migration for Cloud Computing - A Firefly Optimization Approach," J. Grid Comput., vol. 14, no. 2, pp. 327-345, 2016.

[14] M. Mishra and A. Sahoo, "On theory of vm placement: Anomalies in existing methodologies and their mitigation using a novel vector based approach," Proc. - 2011 IEEE 4th Int. Conf. Cloud Comput. CLOUD 2011, pp. 275-282, 2011.

[15] S. Mustafa, B. Nazir, A. Hayat, A. U. R. Khan, and S. A. Madani, "Resource management in cloud computing: Taxonomy, prospects, and challenges," Comput. Electr. Eng., vol. 47, pp. 186-203, 2015.

[16] E. P. Zaw and N. L. Thein, "Improved live VM migration using LRU and Splay tree algorithm," Int. J. Comput. Sci. Telecommun., vol. 3, no. 3, pp. 1-7, 2012.

[17] T. K. Okada, A. D. L. F. Vigliotti, D. M. Batista, and A. G. vel Lejbman, "Consolidation of VMs to Improve Energy Efficiency in Cloud Computing Environments," 2015 XXXIII Brazilian Symp. Comput. Networks Distrib. Syst., no. May, pp. 150-158, 2015.

[18] A. Beloglazov and R. Buyya, "Energy Efficient Resource Management in Virtualized Cloud Data Centers," pp. 826-831, 2010.
[19] Y. Choon and L. Albert, "Energy efficient utilization of resources in cloud computing systems," 2010.

[20] N. Quang-Hung, N. Thoai, and N. T. Son, "EPOBF: energy efficient allocation of virtual machines in high performance computing Cloud," J. Sci. Technol. Vietnamese Acad. Sci. Technol., vol. 51, No. 4B, no. Special on International Conference on Advanced Computing and Applications (ACOMP2013), pp. 173-182, 2013.

[21] G. Von Laszewski, L. Wang, A. J. Younge, and X. He, "Poweraware scheduling of virtual machines in DVFS-enabled clusters," Proc. - IEEE Int. Conf. Clust. Comput. ICCC, 2009.

[22] A. Kochut and K. Beaty, "On strategies for dynamic resource management in virtualized server environments," IEEE Int. Work. Model. Anal. Simul. Comput. Telecommun. Syst. - Proc., pp. 193200, 2007.

[23] S. S. Masoumzadeh and H. Hlavacs, "A Gossip-Based Dynamic Virtual Machine Consolidation Strategy for Large-Scale Cloud Data Centers," Proc. Third Int. Work. Adapt. Resour. Manag. Sched. Cloud Comput. - ARMS-CC'16, pp. 28-34, 2016.

[24] M. Alaul, H. Monil, R. Qasim, and R. M. Rahman, "Incorporating Migration Control in VM Selection Strategies to Enhance Performance," vol. 6 , no. 4, pp. 135-151. 